\title{
Obstacles to Low Quality Water Irrigation of Food Crops in Morogoro, Tanzania
}

\author{
Suzana Samson ${ }^{1}$, Robinson H. Mdegela ${ }^{1}$, Anders Permin ${ }^{2}$, James E. D. Mlangwa ${ }^{1} \&$ Christopher P. Mahonge $^{3}$ \\ ${ }^{1}$ Department of Veterinary Medicine and Public Health, Sokoine University of Agriculture, Morogoro, Tanzania \\ ${ }^{2}$ Denmark Technical University AIS, Anker Engelundsvej 1, 2800 Lyngby, Denmark \\ ${ }^{3}$ Department of Policy Planning and Management, Sokoine University of Agriculture, Morogoro, Tanzania \\ Correspondence: Suzana Samson, Department of Veterinary Medicine and Public Health, Sokoine University of \\ Agriculture, P.O. Box 3021, Morogoro, Tanzania. E-mail: suzy_nyanda@suanet.ac.tz
}

Received: January 4, 2017

Accepted: January 20, 2017 Online Published: March 2, 2017

doi:10.5539/jsd.v10n2p1

URL: https://doi.org/10.5539/jsd.v10n2p1

\begin{abstract}
Knowledge on users' and regulators' views regarding obstacles on the use of low quality water forms the basis for the improvement of water reuse in food crops irrigation. A qualitative study was conducted to assess the obstacles to the use of low quality water for irrigation of food crops in urban and peri-urban areas in Tanzania. The study considered Morogoro urban and peri-urban areas as a case study due to the existence of paddy and vegetable production using the effluent from the waste stabilisation ponds. Both primary and secondary data were used. Primary data were collected through in-depth interviews with 22 key informants, and 4 focus group discussions with farmers. Content analysis was used in this study. Findings show that domestic wastewater was poorly disposed, waste stabilisation ponds as treatment facilities had limited management, and quality monitoring of effluent from the waste stabilisation ponds was limited to permit safe use of the effluent in food crops irrigation. The government officials were of the view that the effluent from the waste stabilisation ponds should not be used for leafy vegetables irrigation while farmers viewed vegetables farming as a quick source of income and livelihood strategy for many years. The study therefore suggests that the relevant agencies should improve the treatment of wastewater and quality monitoring of the effluent for safe use of low quality water for food crops irrigation in urban and peri-urban areas.
\end{abstract}

Keywords: wastewater treatment, waste stabilisation ponds, water reuse, vegetables irrigation, Morogoro

\section{Introduction}

Agriculture is the single largest user of fresh water in the world, accounting for nearly $70 \%$ of all extractions (FAO, 2002; Kalavrouziotis et al., 2011). According to Valipour (2013, 2016 a,b), 46\% of the cultivated areas worldwide are not suitable for rain fed agriculture due to climate changes hence a need to combine both irrigated and rainfed agriculture. The current condition in the world shows that water crisis will be the first challenge in the future as such water management strategies are needed (World Bank, 2010; Valipour, 2013; Valipour and Singh, 2016). Agricultural water management contributes significantly to the reduction of poverty (Valipour, 2016 a, b). Urban and peri-urban agriculture has significant contribution to the poverty reduction by serving as a source of locally available produce and employing a substantial number of people (Keraita et al., 2012, Valipour, 2016 a,b). However, urban and peri-urban areas face limited supply of potable water to meet both the domestic uses and irrigation farming (United Republic of Tanzania [URT], 2002; Fraiture et al., 2010). According to Qadir et al. (2010), farmers in urban and peri-urban areas who are in need of water for irrigation have often no other alternative than using low quality water (LQW). More importantly, it is in these areas where wastewater is generated the most (World Bank, 2010). As such, improved management of this potential source of water could reduce irrigation water scarcity in these areas.

In this study, LQW is used synonymously with treated wastewater to refer to the effluent from the waste stabilisation ponds (WSPs). The WSPs are shallow basins that use natural factors such as sunlight, temperature, sedimentation and biodegradation to treat wastewater or faecal sludge. In addition, WSP treatment systems usually consist of anaerobic, facultative and maturation ponds linked in series (WHO, 2006). The effluent from the last pond in the series is required to be safe for disposal into the environment. Besides, LQW can be 
considered as an alternative source of water for food crops irrigation in water scarcity situations. Proper treatment and good management of treated wastewater provides a reliable source of water during the dry season, permitting multiple crops production throughout the year. In addition, LQW irrigation contributes significantly to sustaining livelihoods, food security and the quality of environment (Keraita et al., 2012).An increased use of LQW in agricultural production has been reported to occur in various countries in the world (Amoah et al., 2007; World Bank, 2010; Keraita et al., 2012). To illustrate this, WHO $(1989,2006)$ reports a global increase in the area irrigated with LQW from $3 \mathrm{M}$ Ha in 1989 to $20 \mathrm{M}$ Ha in 2006. It has been reported further that more than $10 \%$ of the world's population consumes food which is irrigated with LQW (WHO, 2006). For instance, between 50 and $90 \%$ of vegetables consumed by urban dwellers in West Africa are produced within or close to the city where much of the water used for irrigation is of low quality (Qadir and Scott, 2010).

In the developing countries where sub-Saharan Africa falls, the opportunity to use LQW in food crops irrigation cannot be exploited to its full potential due to various obstacles to its safe use. In this study obstacles are defined as aspects that hinder or have potential to hinder safe use of treated wastewater in food crops irrigation. On the one hand, literature has indicated three major aspects faced by any water reuse activity. These are wastewater treatment, water quality control and management (Asano and Cotruvo, 2004; Casani et al., 2005). As such, the obstacles for the use of LQW are also expected to revolve around these aspects. On the other hand, Weckenbrock et al. (2011) categorise obstacles for establishing wastewater irrigation as infrastructural, organisational and legal It can be said that the obstacles for safe use of LQW in food crops irrigation fall under the implementation and enabling environment effectiveness. This contention agrees with the Implementation Theory by Scharpf (1997). The theory asserts that, if various actors are involved in the implementation and in creating an enabling environment, the effectiveness will depend on how the actors are coordinated. Safe use of LQW in food crops irrigation involves more than one actor. Some of the actors are involved in the implementation of activities that are directly linked to the practice such as wastewater collection and treatment as well as effluent quality monitoring. Other actors are involved in creating the enabling environment such as formulation and enforcement of legislations. The study therefore intended to unveil the obstacles from both the implementation of activities and enabling environment related to the use of LQW in food crops irrigation.

Other research findings have indicated lack of appropriate infrastructures as the reason for limited collection and treatment of municipal wastewater (Amoah et al., 2007; Drechsel et al., 2008). With that regard, highly polluted water from surface water bodies are reused for irrigation, predominantly unplanned and unintentionally. In other areas, wastewater treatment plants are not functioning as required. A study conducted in Ghana indicated that only 7 out of 44 smaller treatment plants were functional and probably none met the designed effluent standards (Obuobie et al., 2006). Apart from the wastewater treatment, chemical contaminants can be of concern especially in those countries where industrial development has started and industrial effluent enters domestic wastewater. Limited wastewater collection infrastructures experienced in developing countries also lead to limited wastewater management. As such, the municipal wastewater consists of a mix of both domestic and industrial wastewater. Qadir et al. (2010) report that addressing health risks related to pathogens from domestic wastewater can be easier and less costly than addressing chemical risks from industrial wastewater. This indicates the importance of separating the industrial wastewater from the domestic wastewater. According to Weckenbrock et al. (2011), organisational obstacles are aspects related to how farmers are organised on the use of LQW. Farmers accept health risks for the benefits of their occupation and in the general context of their living conditions where wastewater contact through irrigation might only be one of many sanitary challenges (Qadir et al., 2010). This situation poses challenges for farmers to acknowledge the associated health risks and acceptance of health risks reduction measures. However, in areas where farmers are well organised in using the resource, health risks are well accepted and are already being managed by farmers (Weckenbrock et al., 2011). Since the use of low quality water in food crops irrigation lacks official recognition, the practice is always informal. Informal use of the resource limits health risks management strategies by various stakeholders.

Health risks management will be successful only if a transition is made to a planned strategic reuse programming whereby formal mechanisms to coordinate the actions of multiple government authorities are put in place (Valipour and Singh, 2016). Additionally, WHO (2006) guidelines emphasise the control of the health risks associated with the use of LQW in food crops irrigation, the aspect which cannot be achieved without planned use of the resource. In order to manage the health risks associated with the use of LQW in food crops irrigation, Valipour and Singh (2016) assert that wastewater treatment, regulation and farmer user groups should be included in the comprehensive management approaches. According to Asano and Cotruvo (2004), the strength of planned wastewater reuse is based on the ability to control the potential health risks. This means that, successful planning and management of water reuse in food crops irrigation needs information on the obstacles related to 
management and planning which is unfortunately missing in the Tanzanian context. According to Valipour and Singh (2016), studies on irrigation with treated wastewater have been conducted on other aspects such as soil, ground water, crops, health, irrigation equipment and other environmental issues with limited studies on management. In Tanzania for instance, recent studies concentrated much on the health and socio-economic issues related to the use of LQW (Kilobe et al., 2013; Nyomora, 2015; Mayilla et al., 2015, Msigala et. al. 2017; Samson et al. In press).This paper therefore presents the study findings on the obstacles to the use of LQW for food crops irrigation in Tanzania. The study focused on the obstacles related wastewater collection, wastewater treatment and quality monitoring of treated water in relation to its use in food crops irrigation. This information is important for setting strategies for safe use of treated wastewater in food crops irrigation.

\section{Methodology}

\subsection{Study Area}

The study was conducted in Tanzania at local government and national levels. The research at the latter was carried out at the Ministry whereas at the former was conducted at the regional and district levels. However, the investigation on the actual use of LQW in food crops irrigation was conducted in Morogoro urban and peri-urban areas as a case study. Mafisa area and Changarawe village in Kichangani and Mzumbe wards respectively were selected for the study due to the existence of the WSPs whose effluent was used in food crops irrigation. Farmers in Changarawe village practised vegetable farming using LQW from Mzumbe University WSPs whereas farmers in Mafisa area irrigated paddy using effluent from the Morogoro Urban Water Supply and Sanitation Authority (MORUWASA) WSPs. Changarawe village is $25 \mathrm{~km}$ from Morogoro town and Mafisa area is within Morogoro Municipality. In addition, Changarawe village lies between latitude $6^{\circ} 50^{\prime}$ and $7^{\circ} 0$ ' to the South of Equator and longitude $37^{\circ} 30^{\prime}$ and $37^{\circ} 40^{\prime}$ East of Greenwich while Mafisa study site lies between latitude $6^{\circ} 40^{\prime}$ and $6^{\circ} 50^{\prime}$ to the South of Equator and longitude $37^{\circ} 30^{\prime}$ and $37^{\circ} 40^{\prime}$ East of Greenwich (Figure 1).

\subsection{Study Population and Data Collection}

A qualitative research design was employed whereby data were collected through in-depth interviews, and focus group discussions (FGDs) that were guided by checklists. Secondary data were also collected through reading reports from the relevant authorities involved in wastewater collection and treatment services as well as effluent quality monitoring. In-depth interviews and FGDs were conducted in Kiswahili, the language that all participants were conversant with for easy communication. The transcription was done and later translated into English for analysis.

In-depth interviews: The study involved a total of 22 key informants. Fifteen government officials were from the ministry, regional and district levels; they were assigned to the researcher on the basis of the study objective explained in the introductory letter sent to them prior to the date of the interviews. The government officials were from agriculture, health, environment and water sectors; the sectors which are relevant to the use of LQW in food crops irrigation (WHO, 2006). Additionally, five key informants were selected from the study sites basing on various aspects such as the number of years they had been in the study sites and their being community leaders or influential people. In-depth interviews held with key informants explored issues on the obstacles to the use of LQW in relation to wastewater collection and treatment as well as effluent quality monitoring. Their views on the existing food crops production using LQW from the WSPs were also taken on board.

Focus Group Discussions: In this method there were two groups from each study site and each comprised 6-8 farmers. In order to capture various opinions from farmers on the obstacles for LQW irrigation, farmers for FGDs were selected basing on: i) sex because both men and women were involved in farming activities using LQW; ii) type of vegetables grown particularly in Changarawe village because different types of vegetables were grown and iii) whether the irrigated plots were downstream or upstream the LQW canal because accessibility to LQW varied with location of the plots. However, the participation of farmers in the study was voluntary as the researcher asked for their consent prior to the exercise. FGDs with farmers explored the obstacles on the use of LQW for food crops irrigation in relation to what has been found in the literature as well as the government officials' views on the use of LQW in food crops irrigation. A trained research assistant facilitated all the FGDs while the researcher was taking notes. 


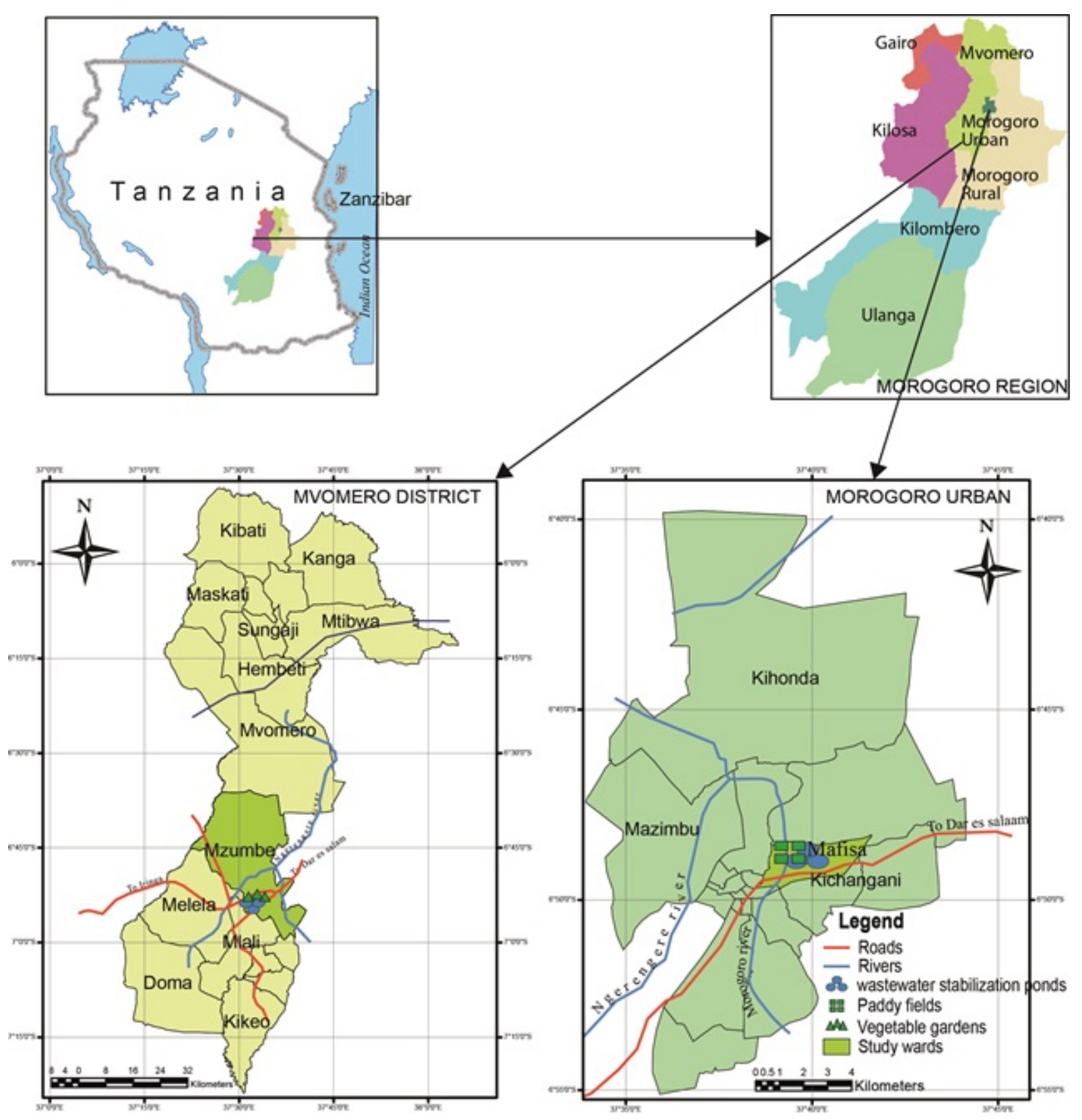

Figure 1. Map of Morogoro Region, Tanzania showing paddy and vegetable growing areas using LQW from the WSPs

Secondary data: Secondary data were obtained from various reports related to wastewater collection and treatment as well as effluent quality monitoring. The reports were collected from relevant offices and/or from the internet. The researcher read all the collected reports one after another and sections or statements relevant to the obstacles for the use of LQW for food crops irrigation were highlighted. The main reports were from MORUWASA and the Energy and Water Utilities Regulatory Authority (EWURA).

\subsection{Data Analysis}

Data were analysed using content analysis method. The researcher went through all the notes made during the in-depth interviews and FDGs. Secondary data were also analysed basing on the issues related to the obstacles for the use of LQW in food crops irrigation. Coding was done in order to label, compile and organise the qualitative data. All related information was grouped into categories. Results were presented in terms of the themes identified supported with some quotes from the comments and statements made by the participants during the FGDs, in-depth interviews as well as sections from the reports. 


\section{Results and Discussions}

Investigations on the obstacles to the use of LQW and its suitability for food crops irrigation in urban and peri-urban areas identified four main themes. The themes identified were wastewater collection practices, industrial wastewater disposal, performance of WSPs in the treatment of wastewater and effluent quality standards compliance monitoring. These themes are presented along with the research respondents' views on the use of LQW in food crops irrigation.

\subsection{Wastewater Collection}

Effluent from the WSPs for crops irrigation is a result of wastewater collected. Major domestic wastewater collection methods identified by the study were sewer networks, cesspits and pit latrines. The cesspits and pit latrines were mentioned to be domestic wastewater collection methods more used than the sewer networks. When commenting on the use of pit latrines, a key informant from Morogoro Municipality said that "The use of pit latrines is due to unplanned settlements, other areas are not accessible by trucks..... some people also have no enough income for constructing improved toilets". Similar findings were reported by Strauss et al. (2006) that on-site sanitation systems predominate over the sewerage system in the urban areas of the developing countries whereby Tanzania was reported to have more than $85 \%$ of its urban population served by on-site sanitation. A study conducted in Dar es Salaam the largest city in Tanzania gave similar result. It indicated that over $80 \%$ of its population of about $3.8 \mathrm{~m}$ people use pit latrines with about $6 \%$ of the dwellers connected to the sewerage system (Chaggu et al., 2002).

In Morogoro Municipality, only $1.7 \%$ of the entire population is connected to sewer network (MORUWASA, 2013). The study results from the in-depth interviews also indicated limitations for the use of cesspits such as construction cost. The system establishment needs flush toilets, septic tanks and soak away pits, which are expensive for ordinary people prompting them to construct pit latrines. Empting the cesspits was also a challenge as the cost was perceived to be high, ranging from TAS 45,000 to 50,000/= (USD 28.1-31.2) per trip of 2,500 litres of wastewater. The costs are not affordable as in other cities worldwide causing people not to frequently empty their septic tanks until when there is drainage blockage (Strauss et al., 2006). Poor accessibility to some places due to un-planned settlements also hinders wastewater collection through cesspits emptier (Ingallinella et al., 2002).

Generally, the results show that limited sewerage coverage is due to the shortage of sewerage system infrastructures as one of the FGD participants in Changarawe village contended: "we have no defined infrastructures for wastewater collection. Most of us have pit latrines, and no much use of water in these latrines that can flow out, a lot of it gets into the soil". The results from the secondary data also show that the shortage of wastewater collection infrastructures is due to lack of priority by the government on wastewater collection. For example, in 2013 the national coverage of sewerage systems was about 9.2\% (URT, 2013). This was further revealed during the in-depth interviews. For example, a key informant from the Ministry of Water declared that "investment was initially focused on clean water supply, so wastewater collection infrastructures were not initially developed". This indicates that wastewater treatment and disposal in urban areas had not been accorded high priority causing wastewater to be haphazardly discharged leading to limited amount of wastewater getting into the WSPs.

The findings clearly indicate limited collection of wastewater, a situation that has effect on the scale of farming using treated wastewater when this resource is used as an alternative source of water (Patel et al., 2014). Dominance of on-site sanitation, in particular the pit-latrines, makes the wastewater to be directly drained into the soil; hence limiting the amount of water for reuse activities. Challenges associated with cesspits emptying in terms of costs limit the collection of wastewater to the WSPs for treatment; as a result, people look for zero cost alternative ways of emptying their toilets. Deliberate emptying of toilets through run- off water during the rainy season is a zero cost wastewater disposal commonly done in un-planned settlements in urban areas. The findings also imply underutilisation of the WSPs due to limited amount of wastewater disposed into the ponds emanating from limited sewer connections and cesspits emptying at the ponds. Moreover, the amount of LQW generated from the ponds could have been higher than the current amount that would have supported larger area under irrigation farming. Unless the wastewater collection is accorded due priority, the existing water sources in urban areas will continue to be polluted due to poor disposal of wastewater leading to indirect use of untreated wastewater in food crops irrigation. Also the existing WSPs will continue to be underutilised such that the potential use of LQW from the ponds will not be realised. The limited amount of LQW generated will only support small area under cultivation.

\subsection{Industrial Wastewater Disposal}


The discharge of untreated wastewater from the Morogoro textile industries into the MORUWASA WSPs was observed as well as reported during FGD with farmers in Mafisa. A participant in Mafisa argued that

“....as far as I know the water from the WSPs can be used for farming activities, the only problem is when it mixes with industrial wastewater..... when the water from the WSPs becomes green we know that it has already mixed up with industrial wastewater".

The results from the secondary data also indicated disposal of untreated industrial wastewater into the environment since most of the existing industries in Tanzania were established without wastewater treatment facilities (URT, 2002). The requirement for industries to establish treatment facilities for wastewater pre-treatment before discharging into public sewage system and/or environment system is not followed. On the other hand, the results from the in-depth interviews with government officials indicate limited use of the pre-treatment facilities for some of the industries that managed to establish the facilities. For example, a key informant from the National Environmental Management Council (NEMC) pointed out that

“.....the treatment facilities are not fully utilised because the technology used adds up the cost of production. They can follow the treatment procedures during the day when they are aware that the government officials might conduct monitoring visits but during the night they skip some of the requirements for proper treatment and dispose the wastewater that is partially or not treated".

Further investigations on the nature of wastewater disposed into the WSPs for treatment indicated limited mechanisms in determining the nature of wastewater disposed into WSPs. In-depth interviews findings from MORUWASA revealed limited follow-up on the composition of the wastewater by MORUWASA. On the other hand, Urban Water Supply and Sanitation Authorities (UWSAs) are required to ensure that the wastewater disposed into the WSPs can be treated to the quality standards that can be disposed to the environment in order to control environmental pollution and safeguard the public health. This can be achieved through undertaking periodic studies to determine type of wastewater generated from various places as mentioned in Section 4.5 of the National Water Policy (URT, 2002), Section 2.1 of the Water Supply and Sanitation Act (URT, 2009a) and Section 76 (1a) of the Public Health Act (URT, 2009b). The UWSAs also have the mandate to permit the discharge of desirable wastewater into the ponds. For example, Section 101(2a(I) of the Public Health Act (URT, 2009b) states that

"a person shall not be permitted to discharge directly or indirectly into any public sewer any matter from a manufacturing process or a factory, other than domestic sewage or storm water, except by a written agreement with the Authority.

Also Section 9 of the regulations regarding compulsory national standards and measures to conserve water (URT, 2001) states that

"A water services institution is only obliged to accept the quantity and quality of industrial effluent or any other substance into a sewerage system that the sewage treatment plant linked to that system is capable of purifying or treating......"

Despite deliberate efforts by the government in enforcing the stipulated laws including the monitoring visits conducted by NEMC, findings from the in-depth interviews with government officials indicate that industries with wastewater treatment facilities use them occasionally. Industries are trying to avoid the costs associated with wastewater treatment. In developing countries like Tanzania where sewerage systems are also not well developed and/or managed, a mix of both domestic and industrial wastewater is common in urban areas (Jiménez, 2006). There is thus no guarantee that the wastewater disposed into the WSPs is purely from the domestic uses. Industrial wastewater is a source of toxic substances or biological process inhibitors (Chove et al., 2006; Jiménez, 2006; Scheierling et al., 2011). Once discharged into the WSPs, it deters the efficiency of the ponds. The toxic substances might kill the microbes responsible for the treatment process resulting into the effluent not meeting the required standards. Legislations enforcement for industries to establish and utilize the pre-treatment facilities for its wastewater is essential in ensuring that industrial wastewater is not disposed into the public sewerage systems and/or environment

\subsection{Wastewater Treatment}

The results from the secondary data indicate that, WSPs are the only centralised wastewater treatment method practiced in the country for the treatment of domestic wastewater though with very limited coverage. A report from EWURA showed that out of 23 Regional Water Supply and Sanitation Authorities only 10 have WSPs in Tanzania Mainland (URT, 2014). The existing WSPs are also not covering the whole municipality population; for example, Morogoro Municipality had only $1.7 \%$ domestic connections for the entire municipality population 
of 315866 people (MORUWASA, 2013;URT, 2013). Indicating that the effluent from the WSPs to be used as a source of water for food crops irrigation will be limited to urban and peri-urban areas where these structures are available unless investments are also made in other areas. Similar findings were reported by Valipour and Singh (2016) that wastewater treatment is limited in many developing countries since investments in this area are not keeping pace with increase in population and the consequent increase in wastewater volume.

Since WSPs were the only centralised treatment systems for domestic wastewater practiced during the study period, the study also investigated the views of the key informants on the quality of effluents for food crops irrigation The views of the key informants were mixed. The water authorities responsible for domestic wastewater treatment using WSPs indicated that the ponds treated the wastewater to the level required. For example, key informant from MORUWASA contended that "the efficiency is good, they perform the way they are supposed, this is indicated by the samples taken every month that show they perform well. You might find slight changes in the required standards, but they generally perform well across the seasons". On the contrary, the results from the in-depth interviews with government officials especially those from the Health Sector indicated uncertainty on the efficiency of the ponds in treating the domestic wastewater to the level that can be used for food crops irrigation. For example, one of the government official interviewed commented that "I once worked in the Ministry of Water in water testing laboratory; we were receiving the water from WSPs for testing and found that the effluent was not meeting the required standards for disposal" (TFDA Key Informant, January 2015). Limited desludging of the ponds limited effluent monitoring and discharging of unwanted industrial wastes containing chemicals into the ponds were the major concerns. For example, a key informant from Morogoro Municipality was of the view that

“.....sediments like sand when piles up reduce the ponds depth ultimately reducing the ponds' efficiency. If the ponds are not cleaned for a long time, the efficiency is reduced because the retention time is reduced, the wastewater will be moving like any moving water without any treatment being effected".

Although a key informant responsible for the management of the Mzumbe University WSPs commented the quality of the effluent was good for food crops irrigation, limited management of the WSPs was also declared. The key informant mentioned on the limited sludge removal but the researcher also observed water hyacinths in the ponds. Further investigation on how regular water hyacinths were removed indicated that, the practice was done at least once per year depending on financial resources availability. This indicates that the practice is not a guaranteed. On the other hand Msigala et al. (2017) found the decrease in the depth of the anaerobic pond of the Mzumbe University WSPs from $2.5 \mathrm{~m}$ to $1.6 \mathrm{~m}$. The reduced pond depth has effects on the efficiency of the ponds in the treatment of the wastewater.

A study conducted in India indicated that operation and maintenance of the treatment plants and sewage pumping stations was not satisfactory as some of the treatment plants were not conforming to the required standards (Patel et al., 2014). However, literature shows that WSPs are effective alternatives for treating domestic wastewater because of their simplicity, low cost, low maintenance, low energy consumption, robustness and sustainability (Machibya and Mwanuzi, 2006; Rahmatiyar et al., 2014). The authors pointed out that, WSPs have been performing below the required standards due to lack of proper operation and maintenance. Therefore, the worries by the key informants from the Health Sector on the quality of the effluents are genuine due to the existing limited management of the WSPs

\subsection{Compliance to Standards}

The effluent from the WSPs is required to meet the quality standards for the wastewater disposal to the environment. From the documentary review findings, the permissible limits for total coliform organisms in the effluent before disposal to the aquatic environment is 10000 counts/100ml (URT, 2005\&2007). The major aim for this limit was to determine the effluent quality as it is released into the environment and on checking the operational efficiency of the wastewater treatment systems. According to WHO (2006) guidelines the wastewater reuse for leafy crops and in labour intensive production situations can be done under a coliform level of not above 10000 counts $/ 100 \mathrm{ml}$. The treatment efficiency of the MORUWASA WSPs in the removal of coliform organisms show less than 10000 count $/ 100 \mathrm{mls}$ for both Escherichia coli load (faecal coliforms) and Salmonella (Mhongole et al., 2016). The ponds have been reported to be highly suitable for treating wastewater for irrigation. Studies in Jerusalem reported an effluent of 1000 faecal coliforms/100ml (Horan, 2003). In terms of five-day Biochemical Oxygen Demand $\left(\mathrm{BOD}_{5}\right)$ for the effluent disposal as per Tanzanian environmental pollution control

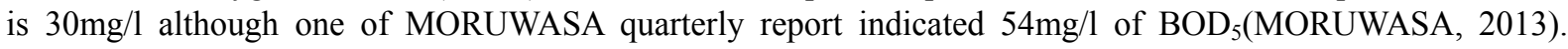
Besides, WHO (2006) recommends a $\mathrm{BOD}_{5}$ of less than $10 \mathrm{mg} / 1$ for water reuse in food crops irrigation. The study results clearly indicate that, the recommended $\mathrm{BOD}_{5}$ level for environmental pollution control in Tanzania 
is higher than the standard required for food crops irrigation.

The study results from both the secondary data and field further indicate that the existing effluent quality compliance monitoring is irrelevant to the international requirements for water reuse in food crops irrigation. According to the Environmental Management Act (URT, 2009c), the designated water quality laboratories are required to undertake assessment of effluent quality standards as prescribed under the Act. The results from the in-depth interview with the key informant from MORUWASA and MORUWASA annual report indicated the effluent quality assessment was conducted monthly and quarterly and parameters tested did not include faecal coliforms (MORUWASA, 2013; URT, 2014). The effluent quality assessment for the Mzumbe WSPs was conducted only once since the ponds were constructed in 1998. On the other hand, WHO (2006) points out that agricultural reuse of water requires weekly monitoring of the Biochemical Oxygen Demand (BOD) and daily monitoring of the faecal coliforms. The results from secondary data indicated limited number of laboratories especially for testing the WSPs effluent. MORUWASA as the water supply and sanitation authority for Morogoro Municipality has laboratories for potable water quality assessments only while the quality assessment for effluent from the WSPs is undertaken in Dar es Salaam which is $200 \mathrm{kms}$ away. Limited effluent quality monitoring creates uncertain environment on its use food crops irrigation. Lack of regular quality monitoring of the effluent makes the safety of the effluent for food crops irrigation questionable. Despite the fact that properly designed and operated WSPs perform well in the removal of faecal coliforms, regular monitoring of the effluent should not be ignored due to human health consequences associated with LQW irrigation (Hussain et al., 2002). Safe use of effluent from the WSPs in food crops irrigation in Tanzania will primarily need improvements in quality monitoring of the effluent in ensuring compliance with the international effluent quality monitoring requirements.

\subsection{Respondents' Views on the Obstacles for LQW Use in Food Crops Irrigation}

Interestingly, all the respondents acknowledged the nutrient value of the effluent from the WSPs. The results from the FGD with farmers and in-depth interviews with key informants indicated that the use of LQW in food crops irrigation leads to increased yield and this is allegedly because the water has nutrients that support plant growth. Despite the nutrient value of the water, the government officials worried about the quality of effluent from the WSPs. Although Tanzania has no state based quality standards for the effluent specific for food crops irrigation, the government officials' worries were based on the existing environment surrounding the wastewater treatment practices in the country. Like many developing countries, quality assurance in Tanzania is questionable as one key informant from TFDA stated “... I am not sure if the low quality water used in food crops irrigation have been taken to the national laboratories for faecal contamination test..."Uncertain environment surrounding the compliance with the national standards as well as limited quality monitoring should not be ignored for the existing water reuse in food crops irrigation. The health risks associated with the practice need quality compliance and monitoring to be enhanced for public health protection.

Generally, the use of effluent from the WSPs for vegetable irrigation was not supported by almost all government officials interviewed. These were of the view that the effluent could be suitable for cereal crops and fruits like citrus. Cereal crops undergo several processing before consumption and their edible parts are always not in contact with water during irrigation. Key informants were not in favour of irrigating vegetables with this water because their edible parts are always in contact with water during irrigation. They further contended that vegetables are not supposed to be over cooked from health point of view; hence some microbial and chemical contaminants can still be a problem. For example a key informant from Morogoro Municipality pointed out that,

“...I cannot recommend for vegetables production, example tomatoes, a person can pick it and eat without washing because some people do not have a culture of washing fruits before eating. But for crops like paddy I do not think there is a big problem because paddy undergoes a lot of processing".

Also a key informant from Morogoro Regional Office mentioned that

"crops to irrigate using this water should be cereals because they dry and are not directly consumed they go through some processing,...... different from vegetables of which leaves are consumed whereby you find vegetables irrigated the same day of harvesting and consumption...... might have bacterial contaminants.........".

These arguments are similar to those reported by Weckenbrock et al., (2011) that many scientists and decision makers have negative perception of LQW irrigation and some would prefer to prohibit the practice.

From the farmers' perspective, the effluent from the WSPs was a very important potential source of water for irrigation. LQW from Mzumbe University ponds is the only source of water for irrigation during the dry seasons. 
In Mafisa area, farmers also found great use of LQW as such they were capable of producing paddy twice a year that could have not been possible under rain fed agriculture. Effluent from WSPs was the only source of water that allowed paddy irrigation during the dry season. Given the reality that no alternative sources of water for irrigation are available to these farmers, effluent from the WSPs will continue to be used as a source of irrigation water. Farmers will also continue to grow crops of their own choice and vegetable farming is a quick source of money during the dry seasons compared to other crops (Keraita et al., 2012). These two different lines of thinking on the use of effluent from the WSPs in food crops between the government and the community especially on vegetables production need a balance. The responsibility of the government is to monitor the health of its population and have an interest in improving it. This is important to farmers who undertake farming using LQW and the consumers who may be exposed to health problems (Starkl et al., 2015). The current use of the effluent is informal with no guiding principles for the practice. Regulatory framework on the use of effluent from the WSPs is required so as to address the obstacles towards the safe use of LQW in food crops irrigation.

\section{Policy Implications}

Water reuse in food crops irrigation is gaining popularity particularly in the water scarce and low income countries. The study has generated information on the obstacles to the use of LQW for food crops irrigation which is very crucial in the planning for water reuse in food crops irrigation. The nature of wastewater collected and treatment methods are some of the key issues for the safe reuse of water in food crops irrigation (Akpor and Muchie, 2011). Wastewater collection systems need to ensure appropriate wastewater is collected and treated with an appropriate method to reach the minimum quality standard for the intended use. The findings in this study have indicated poor wastewater collection and treatment practices implying that there is a need to accord due priority to this aspect. The municipal and city councils should consider wastewater collection and treatment in their planning agenda. In Tanzania, the use of LQW from the WSPs can contribute to achieving the Tanzania Vision 2025 (URT, 2010) on food self-sufficiency and food security. Therefore, Tanzania can invest in ensuring proper collection and treatment of its domestic wastewater such that it meets the quality standards for food crops irrigation. This practice can ensure food security and nutrition in urban and peri-urban areas. The use of LQW from the WSPs as an alternative source of water for food crops irrigation practiced in urban and peri-urban areas can also be considered as an adaptation and mitigation strategy for limited sources of water as a result of climate change. Since some of the cultivated areas worldwide are not suitable for rain fed agriculture due to water scarcity as a result of climate changes (Valipour, $2016 \mathrm{a}, \mathrm{b}$ ), alternative sources of irrigation water in one region can also be applied in other regions. Therefore, the findings from this specific study in this particular location also provide highlights to other locations with similar situations. Thus, wastewater collection, treatment and effluent quality monitoring are among the issues to be taken into account for safe use of LQW in food crops irrigation.

\section{Conclusions}

Lack of alternative source of water for irrigation has forced farmers to use LQW from the WSPs for paddy and vegetables production. However, this water is not utilised to its full potential due to various obstacles. Limited collection of wastewater has resulted into limited LQW generated from the WSPs; hence farmers grow food crops in small plots and sometimes water is not enough to meet irrigation demands. Findings also indicated poor disposal of untreated industrial wastewater due to lack of pre-treatment facilities by industries and/or limited use of the pre-treatment facilities. Unintentional mix of both domestic and industrial wastewater gets into the ponds the situation that might reduce the treatment efficiency of the WSPs. The WSPs as treatment facilities also lack management and regular monitoring of the effluent generated. The worries of government officials on the use of LQW for irrigation of food crops especially the leafy vegetables were centred on these obstacles. However, the government officials acknowledged the nutrient value of LQW as well as its accessibility by farmers as an alternative source of irrigation water during the dry season. Government officials were of the view that the water should not be used for vegetables production but rather it should be used for cereal crops and fruits such as citrus. This is because the current limited WSPs management and effluent quality monitoring exposes both farmers and the consumers of the vegetables to health risks. These findings are in line with the Implementation Theory by Scharpf (1997). These obstacles resulted from ineffectiveness of various actors in the chain of safe use of LQW in food crops irrigation. Coordination of the actors in the chain is required in overcoming these limitations, the aspect that necessitates a clear regulatory framework on the practice. The study suggests that the government specifically the city and regional planning departments to look into the aspect of proper domestic wastewater collection and treatment as one of the development planning agenda. This will be achieved through planned settlement for the emerging urban centres. For the case of poor disposal of industrial wastewater, the government particularly NEMC should strictly enforce the laws for establishment and use of pre-treatment facilities in the 
industries. This will help in maintaining the treatment performance of the WSPs ultimately generating safe water that can be used in food crops irrigation. For the cities with WSPs, the Urban Water Supply and Sanitation Authorities are therefore required to enhance regular monitoring of the quality of the influent and effluent so as to determine point sources of unwanted wastewater and required disposal standards respectively.

\section{Acknowledgments}

This study is part of a PhD, funded by the Danish Ministry of Foreign Affairs through the Safe Water for Food (SaWaFo) Project. The authors acknowledge the Department of Veterinary Medicine and Public Health of Sokoine University of Agriculture for playing a facilitation role towards this achievement. Thanks to the government officials at different levels as well as the farmers and key informants from Changarawe and Mafisa areas for their participation in the study; their time devoted in this study is highly appreciated. The authors are also are thankful to the anonymous reviewers, their constructive comments have significantly improved the quality of the paper.

\section{References}

Akpor, O. B., \& Muchie, M. (2011).Environmental and public health implications of wastewater quality. African Journal of Biotechnology, 10(13), 2379-2387.

Amoah, P., Drechsel, P., Abaidoo, R. C., \& Henseler, M. (2007). Irrigated urban vegetable production in Ghana: Microbiological contamination in farms and markets and associated consumer risk groups. Journal of Water and Health, 5(3), 455-466. https://doi.org/10.2166/wh.2007.041

Asano, T., \& Cotruvo, J. A. (2004). Groundwater recharge with reclaimed municipal wastewater: health and regulatory considerations. Water Research, 38(8), 1941-1951. https://doi.org/10.1016/j.watres.2004.01.023

Casani, S., Rouhany, M., \& Knøchel, S. (2005). A discussion paper on challenges and limitations to water reuse and hygiene in the food industry. Water Research, 39, 1134-1146. https://doi.org/10.1016/j.watres.2004.12.015

Chaggu, E., Mashauri, D., Van Buuren, J., Sanders, W., \& Lettinga, G. (2002). Excreta disposal in Dar-es-Salaam. Environmental Management, 30(5), 609-620. https://doi.org/10.1007/s00267-002-2685-8

Chove, B. E., Ballegu, W. R., \& Chove, L. M. (2006). Copper and Lead levels in two popular leafy vegetables grown around Morogoro Municipality, Tanzania. Tanzania Health Research Bulletin, 8(1), 37-40. https://doi.org/10.4314/thrb.v8i1.14269

Drechsel, P., Keraita, B., Amoah, P., Abaidoo, R.C., Raschid-Sally, L., \& Bahri, A. (2008). Reducing health risks from wastewater use in urban and peri-urban sub-Saharan Africa: applying the 2006 WHO guidelines. Water Science and Technology, 57(9), 1461-1466. https://doi.org/10.2166/wst.2008.245

FAO. (2002). Crops and Drops. Making the Best use of Water for Agriculture. Food and Agriculture Organization of the United Nations, Rome. 123pp.

Fraiture, C., Molden, D., \& Wichelns, D. (2010). Investing in water for food, ecosystems and livelihoods: An overview of the comprehensive assessment of water management in agriculture. Agricultural water Management, 97,495-501. https://doi.org/10.1016/j.agwat.2009.08.015

Horan, N. (2003). Control of pathogenic microorganisms in wastewater recycling and reuse in agriculture. In Mara, D., \& Horan, N. (Eds.), Handbook of Water and Wastewater Microbiology (pp. 241-262). Academic Press.

Hussain, I., Raschid, L., Hanjra, M.A., Marikar, F., \& Hoek, W. V. D. (2002).Wastewater Use in Agriculture. Review of Impacts and Methodological Issues in Valuing Impacts.Working paper No. 37, Safe Use of Wastewater, Excreta and Greywater. Colombo, Sri Lanka. 55pp.

Ingallinella, A. M., Sanguinetti, G., Koottatep, T., Montangero, A., \& Strauss, M. (2002). The challenge of faecal sludge management in urban areas - Strategies, regulations and treatment options. Water Science and Technology, 46(10), 285-294.

Jiménez, B. (2006). Irrigation in Developing Countries Using Wastewater. International Review for Environmental Strategies, 6(2), 229-250.

Kalavrouziotis, I. K., Arambatzis, C., Kalfountzos, D., \& Varnavas, S. P. (2011). Wastewater Reuse Planning in Agriculture: The Case of Aitoloakarnania, Western Greece. Water, 3, 988-1004. https://doi.org/10.3390/w3040988 
Keraita, B., Abaidoo, R. C., Beernaerts, I., Koo-Oshima, S., Amoah, P., Drechsel, P., \& Konradsen, F. (2012). Safe Re-use Practices in Wastewater-Irrigated Urban Vegetable Farming in Ghana. Journal of Agriculture, Food Systems and Community Development, 2(4), 147-158. https://doi.org/10.5304/jafscd.2012.024.004

Kilobe, B. M., Mdegela, R., \& Mtambo, M. M. (2013). Acceptability of Wastewater Resource and its Impact on crop Production in Tanzania: The Case of Dodoma, Morogoro and Mvomero Wastewater Stabilisationsation Ponds. Kivukoni Journal, 1(2), 94-103.

Machibya, M., \& Mwanuzi, F. (2006). Effect of low quality effluent from wastewater stabilisationsation ponds to receiving bodies, case of Kilombero sugar ponds and Ruaha River, Tanzania. Internal Journal Environmental Research and Public Health, 3(2), 209-216. https://doi.org/10.3390/ijerph2006030025

Mayilla, W., Keraita, B., Ngowi, H., Konradsen, F., \& Magayane, F. (2015).Perceived Health Hazards of Low-Quality Irrigation in Water in Vegetable Production in Morogoro, Tanzania. Environment and Pollution, 5(1), 1-13. https://doi.org/10.5539/ep.v5n1p1

Mhongole, O. J., Mdegela, R. H., Kusiluka, L. J. M., \& Dalsgaard. (2016). Removal of Escherichia coli in treated wastewater used for food production in Morogoro, Tanzania. African Journal of Microbiology Research, 10(3), 1344-1350.

MORUWASA. (2013). Morogoro Urban Water Supply and Sanitation Authority. Second Quarter Progress Report 2012 /2013. 12pp

Msigala, S. C., Mabiki, F. P., Styrishave, B., \& Mdegela, R. H. (2017). Performance of wastewater stabilization ponds in treatment of endocrine disrupting estrogens in Morogoro urban and peri-urban, Tanzania. International Journal of Public Health and Epidemiology, 6(1), 305-317.

Nyomora, A. M. S. (2015). Effect of treated domestic wastewater as source of irrigation water and nutrients on rice performance in Morogoro, Tanzania. Journal of Environment and Waste Management, 2(2), 47-55.

Obuobie, E., Keraita, B., Danso, G., Amoah, P., Cofie, O. O., Raschid-Sally, L., \& Drechsel, P. (2006).Irrigated Urban Vegetable Production in Ghana: Characteristics, Benefits and Risks. IWMI-RUAF-CPWF, Accra, Ghana.150pp.

Patel, U. D., Sinha, R. K., \& Patel, M. U. (2014). Sustainable development through effective waste management in India : opportunities at community level. International Journal of Sustainable Human Development, 2(1), $1-7$.

Qadir, M., \& Scott, C. A. (2010). Non-Pathogenic Trade-Offs of Wastewater Irrigation. In Drechsel, P., Scott, A. C., Raschid-Sally, L., Redwood, M., \& Bahri, A. (Eds.), Wastewater Irrigation and Health. Assessing and Mitigating Risk in Low-Income Countries (pp. 101-126). Earthscan, Canada.

Qadir, M., Wichelns, D., Raschid-Sally, L., McCornick, P. G., Drechsel, P., Bahri, A., \& Minhas, P. S. (2010). The challenges of wastewater irrigation in developing countries. Agricultural Water Management, 97(4), 561-568. https://doi.org/10.1016/j.agwat.2008.11.004

Rahmatiyar, H., Salmani, E. R., Alipour, M. R., Alidadi, H., \& Peiravi, R. (2014). Wastewater treatment efficiency in stabilisation ponds, Olang treatment. Iranian Journal of Health, Safety and Environment, 2(1), 217-223.

Samson, S., Mdegela, R. H., Permin, A., Mahonge C. P., \& Mlangwa, J. E. D. (In press). Incentives for low-quality water irrigation of food crops in Morogoro, Tanzania. Environment, Development and Sustainability. https://doi.org/10.1007/s10668-016-9895-3

Scharpf, F. W. (1997). Games Real Actors Play. Actor-CenteredInstitutionalism in Policy Research. West view Press, USA. 318pp.

Scheierling, S. M., Bartone, C. R., Mara, D. D., \& Drechsel, P. (2011). Towards an agenda for improving

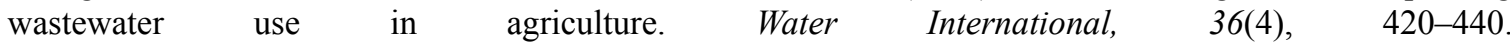
https://doi.org/10.1080/02508060.2011.594527

Starkl, M., Brunner, N., Amerasinghe, P., Mahesh, J., Kumar, D., Asolekar, S. R. Sarah, S. (2015). Stakeholder Views, Financing and Policy Implications for Reuse of Wastewater for Irrigation: A Case from Hyderabad, India. Water, 7, 300-328. https://doi.org/10.3390/w7010300

Strauss, M., Koné, D., Koanda, H., \& Steiner, M. (Eds.). (2006). Urban excreta management - situation, challenges, and promising solutions. Water and Sanitation in Developing Countries. International Faecal Sludge Management Policy Symposium and Workshop, Dakar, Senegal, 9-12 May, 2006. 12pp. 
URT. (2001). The National Regulations relating to compulsory national standards and measures to conserve water. Government Printer, Dar es Salaam, Tanzania. 8pp.

URT. (2002). National Water Policy. Ministry of Water and Livestock Development. Government Printer, Dar es Salaam, Tanzania. 46pp.

URT. (2005). Tanzania Bureau of Standards. National Environmental Standards Compendium. Government Printer, Dar es Salaam, Tanzania. 74pp.

URT. (2007). Environmental Management Water Quality Standards Regulations. Government Printer, Dar es Salaam, Tanzania. 28pp.

URT. (2009a). The National Water Supply and Sanitation Act. Government Printer, Dar es Salaam, Tanzania. $47 \mathrm{pp}$.

URT. (2009b). National Public Health Act. Ministry of Health, Government Printer, Dar es Salaam, Tanzania. $105 \mathrm{pp}$.

URT. (2009c). The National Water Resources Management Act. Government Printer, Dar es Salaam, Tanzania. $73 \mathrm{pp}$.

URT. (2010). The Tanzania Development Vision 2025.Planning Commission, Dar es Salaam, Tanzania. 31pp.

URT. (2013). Water utilities performance review report 2012/2013.Regional Water Utilities and DAWASCO. Dar es Salaam, Tanzania. 151pp.

URT. (2014). Energy and Water Utilities Regulatory Authority Annual Report. Dar es Salaam, Tanzania. 112pp.

Valipour, M. (2016a). How do different factors impact agricultural water management? Agriculture, (1), 89-111.

Valipour M. (2016b). Variations of land use and Irrigation for Next Decades under Different Scenarios. Irrigation: Brazilian journal of irrigation and drainage, 1(1), 262-288.

Valipour, M. (2013). Necessity of Irrigated and Rainfed Agriculture in the World. Irrigation Drainage Systems Engineering. S9: 001.

Valipour, M., \& Singh, V. P. (2016). Global Experiences on Wastewater Irrigation: Challenges and Prospects, Balanced Urban Development: Options and Strategies for Liveable Cities, 289-327, Berlin, Germany, 2016.

Weckenbrock, P., Evans, A., Majeed, M. Q., Ahmad, W., Bashir, N., \& Drescher, A. (2011). Fighting for the right to use wastewater: what drives the use of untreated wastewater in a peri-urban village of Faisalabad, Pakistan? Water International, 36(4), 522-534. https://doi.org/10.1080/02508060.2011.596323

WHO. (1989). Guidelines for the safe use of wastewater and excreta in agriculture and aquaculture. Measures for public health protection. World Health Organisation, Geneva. 187pp.

WHO. (2006). WHO Guidelines for the Safe Use of Wastewater, Excreta and Greywater. Volume I. Policy and Regulatory Aspects. 100.

World Bank. (2010). Improving Wastewater Use in Agriculture - An Emerging Priority. Policy Research Working Paper 5412. The World Bank. 169pp.

\section{Copyrights}

Copyright for this article is retained by the author(s), with first publication rights granted to the journal.

This is an open-access article distributed under the terms and conditions of the Creative Commons Attribution license (http://creativecommons.org/licenses/by/4.0/). 